\title{
Effect of a low-protein diet on the serum proteins of kittens
}

\author{
By BETTY L. COLES \\ Department of Physiology, Royal Free Hospital School of Medicine, London, W.C. I \\ (Received 29 fuly I959-Revised 2 May I960)
}

From the available literature it appears that the protein requirements of cats are high by comparison with those of other species. Dickinson \& Scott (1956b) found that satisfactory growth of kittens could not be maintained if the protein content of the diet on the dry-weight basis was below $30 \%$, and Greaves (1959) found $32 \%$ protein necessary for growth. My work was undertaken in order to determine the effect on the serum proteins of growing kittens of a diet containing $21 \%$ protein on the dry-weight basis, thus providing a protein content 10 \% lower than that regarded as able to support satisfactory growth.

\section{EXPERIMENTAL}

Diet. The composition of the diet is shown in Table I. It was kindly supplied by Petfoods Ltd, Melton Mowbray, in $200 \mathrm{~g}$ tins ready for use. Each kitten was given $150-200 \mathrm{~g}$ daily in two meals.

Table I. Composition of the low-protein* diet

\begin{tabular}{lclc} 
Ingredient & Parts & \multicolumn{1}{c}{ Ingredient } & Parts \\
Minced raw potato & 70 & Minced whole herring & 50 \\
Wood flour & 14 & Minced liver & 14 \\
Starch & 7 & Salt & $\frac{1}{2}$ \\
Mutton fat & 5 & Water & 55 \\
Calfos $\dagger$ & 4 & & \\
$* 21 \cdot 4 \%$ on the dry-weight basis. & & \\
+ 'Edible bone phosphate' (Calfos Ltd, London); calcium $33 \cdot 7 \%$, phosphorus $15 \cdot 2 \%$.
\end{tabular}

Animals. Fourteen kittens, seven male and seven female from three litters whose mothers were designated $\mathrm{P}, \mathrm{MP}$ and $\mathrm{I} 6 \mathrm{M}$, were used for the experiment. All were Io weeks old when they first received the diet and had previously been weaned on to the normal stock diet of the colony, containing about $50 \%$ protein (Dickinson \& Scott, $1956 a$ ). One litter of six kittens (litter MP) received a supplement of oxytetracycline in a lactose base during the weaning period and throughout the experiment. The supplement, $\mathrm{I} g$ of which contained $\mathrm{I} \mathrm{mg}$ oxytetracycline, was given at the rate of $5 \mathrm{~g} / 100 \mathrm{~g}$ food with the morning meal, each kitten thus receiving $5 \mathrm{mg}$ oxytetracycline daily. Litter-mates were not used as controls; all kittens in the three litters were given the experimental diet and their weights and serum-protein values were compared with those of kittens reared under the standard colony conditions.

Serum analysis. The serum was examined before the kittens were given the 
experimental diet, after I, 2, 3, 4 and 6 and, with litter P, 8 weeks on the diet. Litter MP was killed after 6 weeks on the diet; the other litters were returned to the stock diet and bled again after $1,2,4,6$ and 8 or ro weeks of refeeding. Blood was obtained from a vein in the forepaw without anaesthesia and allowed to clot at room temperature. Paper electrophoresis was carried out in a vertical tank of the type described by Flynn $\&$ de Mayo (I95I). Whatman paper no. $3 \mathrm{I}$ was used with a barbiturate buffer of $\mathrm{pH} 8.6$ and ionic strength 0.05 and serum samples of $0.05 \mathrm{ml}$. The runs were for $16 \mathrm{~h}$ at a current of $0.25 \mathrm{~mA} / \mathrm{cm}$ width of paper and a potential of $120 \mathrm{~V}$. After drying, the strips were stained with $0.01 \%$ bromophenol blue by the method of Block, Durrum \& Zweig (I955). Quantitative estimations of the individual fractions were made by the method of Levin \& Oberholzer (1953). The sum of the fractions was checked against the total protein as measured by the micro-Kjeldahl technique.

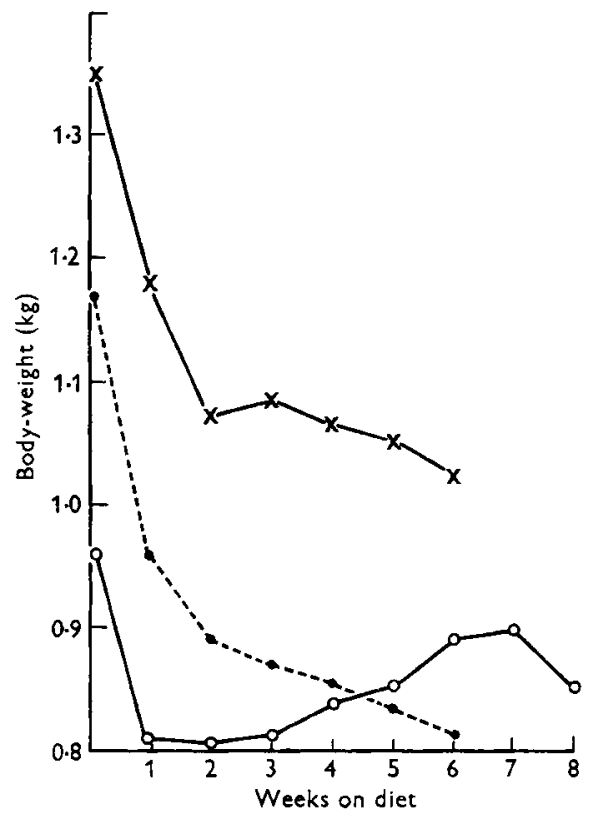

Fig. I

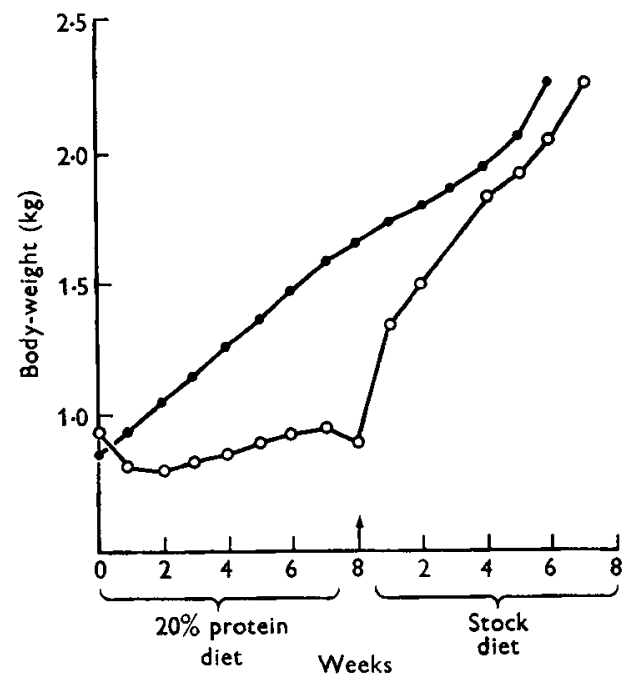

Fig. 2

Fig. I. Mean body-weights of kittens from three litters while on a diet containing about $20 \%$ protein. $0 \longrightarrow 0$, litter P; $\bullet--\bullet$, litter $\mathrm{M} ; \times-\times$, litter MP.

Fig. 2. Mean body-weights of four kittens from litter $P$ while on a diet containing about $20 \%$ protein and after return to stock diet (about $50 \%$ protein). Weights of normal colony kittens of similar age are shown for comparison. $\bigcirc-0$, litter $\mathrm{P} ; \bullet-$ normal kittens.

\section{RESULTS}

Changes in weight. The weights of the three litters during the period on the experimental diet are shown in Fig. I. Litter P, with a considerably lower mean weight at the beginning of the period, lost very much less weight than did the other litters, and gained from the 2 nd to the 7 th week on the diet. Fig. 2 shows the rapid recovery of this litter after return to the stock diet.

Changes in serum protein. The changes in the serum-protein pattern are shown in 
Figs. 3-5. Similar changes were seen in all three litters. The contents of total protein and albumin fell during the period of low-protein feeding, and after the re-introduction of the stock diet rose steadily to normal values for age. The changes in the globulins were slight and inconstant during the time on the diet, but after refeeding

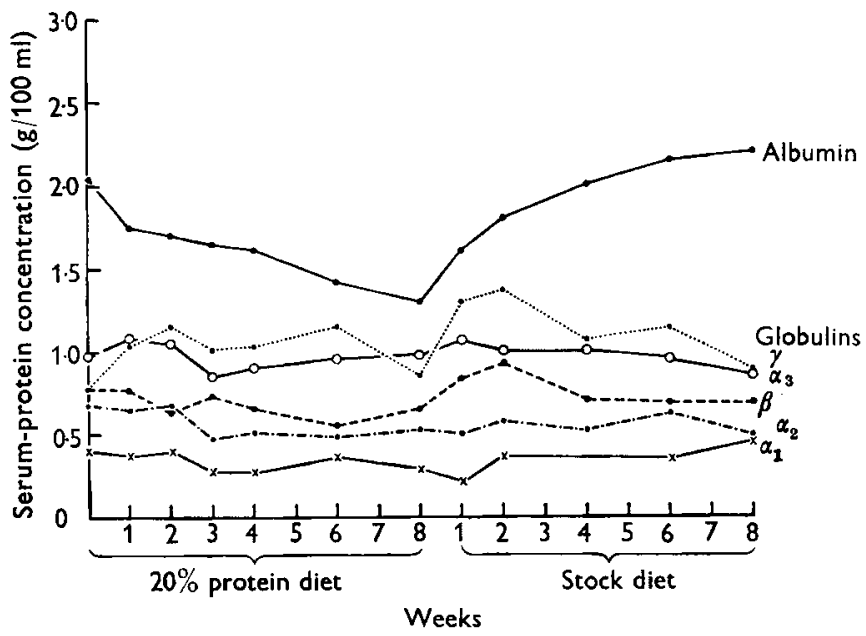

Fig. 3. Mean serum-protein pattern of four kittens from the litter $\mathbf{P}$ while on a diet containing about $20 \%$ protein and after return to stock diet (about $50 \%$ protein).

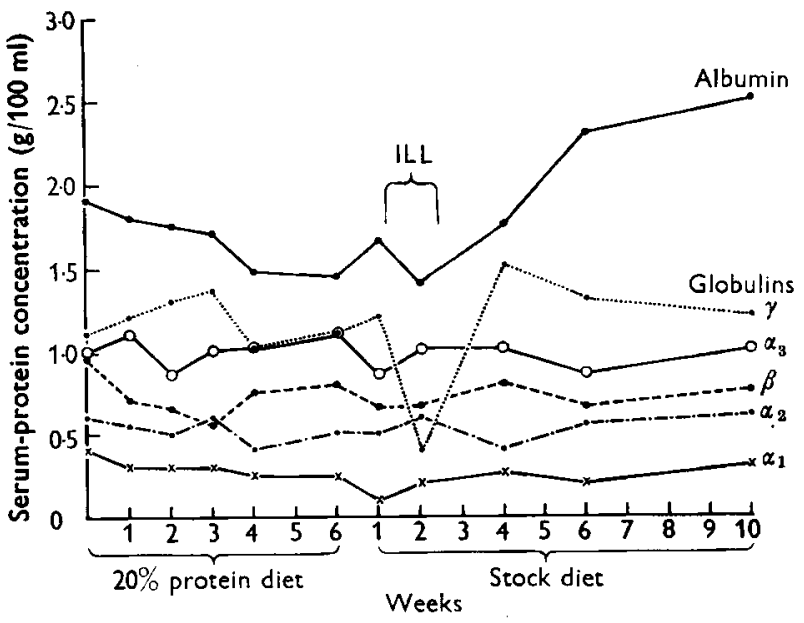

Fig. 4

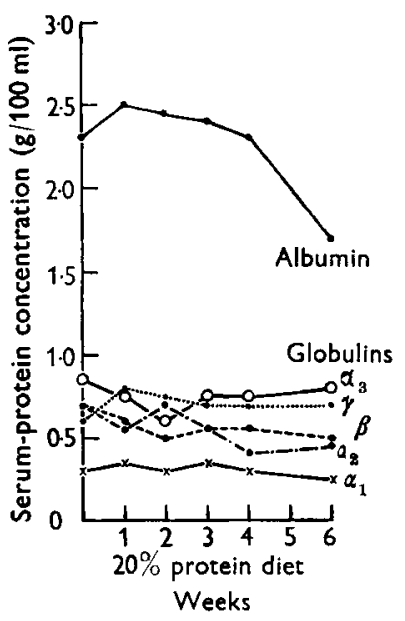

Fig. 5

Fig. 4. Mean serum-protein pattern of four kittens from litter $16 \mathrm{M}$ while on a diet containing about $20 \%$ protein and after return to stock diet (about $50 \%$ protein).

Fig. 5. Mean serum-protein pattern of six kittens from litter MP during 6 weeks on a diet containing about $20 \%$ protein.

with stock diet litter $\mathrm{P}$ showed a marked peak in $\alpha_{3^{-}}, \beta$ - and $\gamma$-globulins during the first 2 weeks. The values then fell to normal. Litter $16 \mathrm{M}$ of four kittens developed a gastro-intestinal infection during the and week on the stock diet which proved fatal 
to one of the kittens. During this illness the total protein and $\gamma$-globulin contents fell sharply and that of albumin to a lesser extent. In one kitten the $\gamma$-globulin content fell from $\mathrm{I} \cdot 135$ to $0 \cdot 195 \mathrm{~g} / 100 \mathrm{ml}$. By the $4^{\text {th }}$ week on the stock diet clinical recovery was complete and the $\gamma$-globulin content had risen to a normal value. Afterwards, return to the normal pattern proceeded as in litter $P$.

Table 2. Mean percentage loss of weight and fall in serum albumin content of the kittens during 6 weeks on the low-protein diet

$\begin{array}{lcc}\text { Litter } & \begin{array}{c}\text { Loss of } \\ \text { weight }\end{array} & \begin{array}{c}\text { Fall in serum } \\ \text { albumin }\end{array} \\ \text { P } & 3.8 & 29.3 \\ \text { I6M } & 24.7 & 23.5 \\ \text { MP } & 23.0 & 25.9\end{array}$

The percentage losses of initial body-weight and of initial serum albumin content after 6 weeks on the experimental diet are shown in Table 2. It should be noted that whereas all litters lost about the same proportion of serum albumin, the weight loss of litter $\mathrm{P}$ was significantly less than that of the other two.

Another finding was the appearance of an abnormal protein fraction with a mobility between those of the $\alpha_{3}$ - and $\beta$-globulins. This fraction appeared in the serum of all kittens at various times between the 2 nd and 3 rd weeks on the diet. It persisted during the recovery period but disappeared in those kittens studied for ro weeks on the stock diet. The content of this fraction appeared to be unrelated to that of any other fraction at any given time and was also unrelated to weight change of the kittens, either gain or loss, during any given week. Its value varied between $0.15^{\circ}$ and $0.660 \mathrm{~g} / 100 \mathrm{ml}$. For the sake of clarity this fraction is omitted from Figs. 3-5. Its possible significance is discussed on p. 423 .

\section{DISCUSSION}

A severe loss of weight by the kittens was to be expected, and the slight loss by litter $\mathrm{P}$ was surprising. After 8 weeks on the experimental diet these kittens had lost only $7.8 \%$ of their initial weight. This litter was only of average weight at the beginning of the experiment, whereas the other litters were well above the normal weight for the colony kittens (Dickinson \& Scott, $1956 a$ ). It has been shown that negative nitrogen balance occurs less readily in individuals already depleted of nitrogen by infection or dietary deficiency than in those previously well nourished (Weech, Goettsch \& Reeves, 1935 $a$; Peters, 195०; Allison, Miller, McCoy \& Brush, 1956). From the results obtained by these authors it was to be expected that the litter showing only minimal weight loss would also maintain their albumin level better than the other litters, but it was not so.

The unusually high mean weight of litter MP at the beginning of the experiment may be attributed to the oxytetracycline supplement. Oxytetracycline has been reported as effective in increasing weight gain in weanling rats (Uram, French, Barron \& Swift, 1955) and also in improving growth in rats fed on a diet with $9 \%$ casein. The addition of tryptophan or the increase of protein to the $25 \%$ level rendered 
the oxytetracycline ineffective (Waisman \& Boldt, 1957). With cats, Dickinson \& Scott (I954) found that both penicillin and chlortetracycline produced increased growth and an improvement in general condition. Chlortetracycline led to slight increase in the content of plasma proteins in young pigs fed on a low-protein diet, but no change in plasma protein was noted at higher levels of protein feeding (Burnside, Grummer, Phillips \& Bohstedt, r95 I). By contrast Dessi \& Gianni (1955) noted a fall in content of albumin and $\gamma$-globulin in rats after treatment with oxytetracycline. The kittens that received the oxytetracycline supplement in our experiment had higher initial albumin levels than the other kittens and these levels were well maintained until the last weeks on the experimental diet, which suggests that the beneficial effect of the antibiotic was continued during the period of low-protein feeding.

Serum-protein changes. The findings in kittens were the same as reported for proteindepleted dogs, a marked fall in content of total protein and albumin but no gross change in the globulins (Kerr, Hurwitz \& Whipple, 1918; Weech, Snelling \& Goettsch, 1933; Weech et al. 1935a; Chow, I946; Zeldis, Alling, McCoord \& Kulka, I945a). The relative increase in $\alpha$-globulin found by Cartwright, Smith, Brown $\&$ Wintrobe (1948) in hypoproteinaemic pigs was not found. The peak in globulins during the recovery period noted in depleted dogs was also present in litter $\mathrm{P}$ which made uninterrupted progress after return to a high-protein diet. The recovery was extremely quick, as found by Weech $e t$ al. (1935a) in dogs. They stated that anorexia was the principal obstacle in rehabilitation, and it was certainly so with the MP litter which refused to eat the stock diet at the end of 6 weeks of low-protein feeding, though no difficulties were encountered with the other animals. The kittens (litter $16 \mathrm{M}$ ) that developed infection during the 2 nd week of refeeding showed a sharp drop in globulin content during their illness. The normally fed cat shows a marked increase in this fraction during infection and this abnormal response would seem to be directly attributable to the period of low-protein feeding preceding the infection (Coles, 1959). Krebs (1946) described a case of hypogammaglobulinaemia due to dietary deficiency which was rectified by high-protein feeding. Spain, Bradess \& Greenblatt (1956) suggested that infants with severe enteric infection and resultant nutritional disturbances might develop depletion of $\gamma$-globulin, which is apparently what happened with our kittens.

The absence of oedema in the kittens requires comment. Weech et al. (1935b) stated that the mean albumin level at which oedema occurred in dogs was $\mathrm{I} \cdot 53 \mathrm{~g}$ / $100 \mathrm{ml}$. Seven out of thirteen of the kittens had values below this figure but the mean value for total protein for all kittens at the end of the experiment was $4.90 \mathrm{~g} / 100 \mathrm{ml}$ as compared with the figure of $4.26 \mathrm{~g} / 100 \mathrm{ml}$ given by Weech et al. This higher total protein may have had some effect in preventing the appearance of oedema, but it is more likely that a species difference was responsible.

Zeldis et al. (1945 $a, b)$ found an additional globulin in protein-depleted dogs in a position analogous to the abnormal fraction seen in the kittens. An abnormal electrophoretic boundary was also reported by Perlmann, Glenn \& Kaufman (1943) after injury by burning, and it is possible that such a protein might have been produced in the kittens as a result of tissue breakdown due to the low protein intake. 


\section{SUMM ARY}

I. The serum-protein pattern in three litters of kittens on a diet with $20 \%$ protein was studied for 6-8 weeks. All kittens were ro weeks old when they first received the diet and had been weaned on to the normal colony stock diet (50\% protein). Two litters were then given the stock diet for 8-ro weeks and the changes with recovery were studied. The protein pattern and body-weight were compared with those of normal colony kittens of similar age.

2. All litters lost weight rapidly during the first 2 weeks on the experimental diet. One litter then gained slowly, the other litters continued to lose at a slower rate. After refeeding with stock diet all kittens rapidly regained weight.

3. An abnormal protein fraction appeared in the serum during the low-protein feeding and its significance is discussed.

4. One litter developed infection during the recovery period. These kittens showed a steep fall in serum $\gamma$-globulin content during their illness. This abnormal response to infection is attributed to previous protein depletion.

I would like to thank the late Professor E. M. Killick for her advice and criticism and Miss A. Elkins, Mr T. Holland and Mr M. Burrows for valuable help in the care of the animals. This work was supported by the Endowment Fund of the Royal Free Hospital and formed part of a thesis accepted for the degree of Ph.D. by the University of London.

\section{REFEREN CES}

Allison, J. B., Miller, S. A., McCoy, V. M. D. \& Brush, M. K. (1956). N. Amer. Vet. $37,38$. Block, R. J., Durrum, E. L. \& Zweig, G. (1955). A Manual of Paper Electrophoresis. New York: Academic Press Inc.

Burnside, J. E., Grummer, R. H., Phillips, P. H. \& Bohstedt, G. (1951). F. Anim. Sci. 1o, 1042.

Cartwright, G. E., Smith, E. L., Brown, D. M. \& Wintrobe, M. M. (1948). F. biol. Chem. 176, 585. Chow, B. F. (1946). Ann. N.Y. Acad. Sci. 47, 297.

Coles, B. L. (1959). Comparative studies of the serum protein pattern in nutritional disorders in infants and kittens. Ph.D. Thesis, University of London.

Dessi, P. \& Gianni, A. M. (1955). Boll. Soc. ital. Biol. sper. 31, 753.

Dickinson, C. D. \& Scott, P. P. (1954). Brit. F. Nutr. 8, 380 .

Dickinson, C. D. \& Scott, P. P. (1956a). Brit. F. Nutr. 10, 304.

Dickinson, C. D. \& Scott, P. P. (1956b). Brit. $¥$. Nutr. 10, 3 11.

Flynn, F. V. \& de Mayo, P. (195I). Lancet, 261, 235.

Greaves, J. P. (1959). The nutrition of the cat: protein requirements and other studies. Ph.D. Thesis, University of London.

Kerr, W. J., Hurwitz, S. H. \& Whipple, G. H. (1918). Amer. F. Physiol. 47, 356.

Krebs, E. G. (1946). I. Lab. clin. Med. 31, 85 .

Levin, B. \& Oberholzer, V. G. (1953). Amer. F. clin. Path. 23, 205.

Perlmann, G. E., Glenn, W. W. L. \& Kaufman, D. (1943). F. clin. Invest. 22, 627.

Peters, J. P. (1950). Nutr. Rev. 8, 33.

Spain, D. M., Bradess, V. A. \& Greenblatt, I. J. (1956). Ann. N.Y. Acad. Sci. 66, I76.

Uram, J. A., French, C. E., Barron, G. P. \& Swift, R. W. (r955). F. Nutr. 55, 481.

Waisman, H. A. \& Boldt, L. C. (1 957). F. Nutr. 61, 457.

Weech, A. A., Goettsch, E. \& Reeves, E. B. (1935a). Ұ̈. exp. Med. 61, 299.

Weech, A. A., Goettsch, E. \& Reeves, E. B. (1935b). F. $\exp$. Med. 61, 7 I 7.

Weech, A. A., Snelling, C. E. \& Goettsch, E. (1933). F. clin. Invest. 12, 193.

Zeldis, L. J., Alling, E. L., McCoord, A. B. \& Kulka, J. P. (1945a). F. exp. Med. 82, I57.

Zeldis, L. J., Alling, E. L., McCoord, A. B. \& Kulka, J. P. (r945b). F. exp. Med. 82, 4 I I. 